\title{
Role of rootstock and apple fruit tissue in antioxidant activity
}

\author{
Tomo Milošević ${ }^{1}$, Nebojša Milošević ${ }^{2}$, Jelena Mladenović ${ }^{3}$ \\ ${ }^{1}$ Department of Fruit Growing and Viticulture, Faculty of Agronomy, University \\ of Kragujevac,32000 Čačak, Republic of Serbia \\ ${ }^{2}$ Department of Pomology and Fruit Breeding, Fruit Research Institute, Čačak, \\ 32000 Čačak, Republic of Serbia \\ ${ }^{3}$ Department of Chemistry and Chemical Engineering, Faculty of Agronomy, \\ University of Kragujevac, 32000 Čačak, Republic of Serbia \\ Corresponding author: tomomilosevic@kg.ac.rs
}

\begin{abstract}
During two consecutive years (2018 and 2019) we investigated the effect of two clonal rootstocks on fruit weight, contents of some non-nutrients and total antioxidant capacity (TAC) in the flesh and peel of $c v$. 'Hapke' apple. Results showed that fruit weight was significantly higher on M.9 T337 than on M.26 rootstock and similar in both 2018 and 2019. M.26 rootstock significantly improved titratable acidity (TA), vitamin C content, total phenolic content (TPC), total flavonoid content (TFC) and TAC in comparison with M.9 T337. As regards fruit tissue, the peel was a significantly better source of acids, vitamin $\mathrm{C}$ and phenolic compounds, and had higher antioxidant capacity than the flesh. However, the rootstock $\times$ fruit tissue interaction for the content of phenolic compounds indicated the complex nature of accumulation and distribution of acidity, vitamin $\mathrm{C}$ and phenolic compounds in apples.
\end{abstract}

Keywords: apple fruit tissue, phenolic compounds, total antioxidant capacity, vitamin C. 


\section{Introduction}

Apple (Malus $\times$ domestica Borkh.) is a very popular fruit crop worldwide, with an annual production of more than 83 million tonnes in 2017 (FAOSTAT, 2019), ranking fourth after grapes, citrus and bananas. Its beautiful appearance, crispy flesh, pleasant flavour and sweet taste attract consumers and fetch a high price (Asif Ali et al., 2004).

Fruit quality is determined by external and internal (morphophysical, biochemical and organoleptic or sensorial) factors. Therefore, fruit physical and chemical properties play an important role for both producers and consumers. Among them, fruit size, contents of organic matter (sugars, acids, pectins, tannins, starch, cellulose, vitamins, enzymes, phytohormones, phenolic compounds etc.) and biogenic macro- and microelements ( $, \mathrm{P}, \mathrm{K}, \mathrm{Ca}, \mathrm{Mg}, \mathrm{S}$ and $\mathrm{Fe}$ ) are the most important for consumers (Nour et al., 2010; Milošević et al., 2014, 2018). However, in recent years, this nutritional doctrine has changed. Namely, consumers prefer fruits and vegetables not only rich in primary metabolites, but also rich in phenolic compounds with high antioxidant activity i.e. health benefits for the human body (Milošević et al., 2018). As known, the chemical composition of apple fruit is very complex since it depends on fruit cultivar, ripeness, physiological condition of the tree as well as on soil and weather conditions (Markuszewski and Kopytowski, 2008) and fruit tissue (Wolfe et al., 2003; Chinnici et al., 2004; Leccese et al., 2009; Milošević et al., 2018).

Among cultivars grown in Serbian apple orchards, old and newly selected clones of the 'Red Delicious' group are widespread. It is well known that the characteristic shape of 'Red Delicious' and its clones is the elongated fruit with well-developed calyx lobes (Koukourikou-Petridou et al., 2014). 'Hapke' is a clone of the 'Red Delicious' family distinguished by these traits (Milošević et al., 2014; Tabakov et al., 2016). For the planting of modern commercial apple orchards with 3,000-5,000 trees per hectare, rootstocks such as M.9 T337 with numerous clones (especially NAKB T333) are used in Serbia and worldwide, and also M.26 in some cases (Paunović et al., 2015; Milošević et al., 2018). As previously noted, apple cultivar and fruit tissue may have a paramount influence on fruit chemical properties, especially phenolic content and total antioxidant activity (Drogoudi et al., 2008). The effect of rootstock on these properties in apples is less known because it has not been widely tested. Some sporadic results were obtained by Mainla et al. (2011) in Estonia, Kviklys et al. (2014) in Lithuania and Milošević et al. (2018) in Serbia. For these reasons, the main goal of the present work was to describe variability in the fruit weight and content of some bioactive compounds in the peel and flesh tissue of 'Hapke' apple grafted on two dwarf clonal rootstocks (M.9 T337 and M.26) grown under western Serbian conditions. 


\section{Material and method}

The privately owned apple orchard located in Prislonica village $\left(43^{\circ} 57^{\prime} \mathrm{N}\right.$, $20^{\circ} 26^{\prime}$ E) near the town of Čačak (western Serbia) used in this research was established in 2006 in a randomised block design with 5 trees of each rootstockcultivar combination in four replicates $(n=20)$. Standard cultural practices were applied, with the exception of irrigation. Fruits from apple cv. 'Hapke' grafted on M.9 T337 and M.26 rootstocks were harvested at commercial maturity in 2018 and 2019. For fruit weight determination, 25 fruits in four replicates $(n=100)$ were measured with a MAULsteel $5000 \mathrm{G}$ digital balance (Jakob Maul GmbH, Bad König, Germany) in both years.

Fruit sampling i.e. flesh and peel sampling for chemical analysis was performed using the procedure described earlier in our similar investigation (Milošević et al., 2018). Titratable acidity (TA) was determined by titration with $0.1 \mathrm{~N} \mathrm{NaOH}$ solution up to $\mathrm{pH} 8.1$ using a Metrohm $719 \mathrm{~S}$ titration device (Titrino, Herisau, Switzerland) and was expressed as percent of malic acid. Ascorbic acid (vitamin C) was determined by the 2,6-dichloroindophenol method (Arya et al., 2000). Data are given as milligrams per $100 \mathrm{~g}$ fresh weight (mg/100 $\mathrm{g}$ fw).

Total phenolic content (TPC) was determined spectrophotometrically using the Folin-Ciocalteu method (Singleton et al., 1999). Values were expressed as milligrams of gallic acid equivalent (GAE) per $100 \mathrm{~g} \mathrm{fw}(\mathrm{mg}$ GAE/100 g fw). Total flavonoid content (TFC) was measured by the aluminium chloride colorimetric assay (Zhishen et al., 1999) using catechin equivalent (CE) as a standard. TFC was expressed as milligrams of CE per $100 \mathrm{~g} \mathrm{fw}(\mathrm{mg} \mathrm{CE} / 100 \mathrm{~g}$ $\mathrm{fw}$ ). TAC was evaluated by the phosphomolybdenum method (Prieto et al., 1999). Ascorbic acid (AA) was used as standard and TAC was expressed as $\mu \mathrm{g}$ of AA per $g$ fw $(\mu \mathrm{g} \mathrm{AA} / g$ fw).

All compounds were estimated by using a UV-VIS spectrophotometer model MA9523-SPEKOL 211 (Iskra, Horjul, Slovenia). Their contents were expressed as means \pm SE of triplicate analyses per rootstock and fruit tissue in both years.

All data in the present study were subjected to analysis of variance (two-way ANOVA) and means were separated by LSD test at $P \leq 0.05$.

\section{Results and discussion}

Apple fruit weight and fruit size are important factors influencing consumer acceptance and orchard profitability. For these reasons, pomologists want to know which practices and treatments influence mean fruit weight and mean fruit value (Marini et al., 2001). Fruit weight as a cultivar-specific property can be improved by cultural practices such as fertilisation, irrigation, pruning, thinning, spraying with foliar nutrients and hormones etc. (Greenhalgh et al., 1977; Milošević et al., 2014, 2019), crop load, rootstock (Milošević et al., 2018) and 
choice of environmental conditions suitable for apple growing. In the present study, significantly higher fruit weight was found in 'Hapke' on M.9 T337 in comparison with M.26 (Table 1). These results were expected due to the higher yield produced by M.26 rootstock in both years (data not shown). In our earlier study we found similar fruit weight values for this cultivar (Milošević et al., 2014).

Year-by-year variations in fruit weight were not observed, as indicated by the stronger effect of rootstock than season, which is in agreement with the results of other researchers (Tabakov et al., 2016). The effect of the rootstock $\times$ year interaction on this property was also not significant.

Table 1. Average fruit weight of 'Hapke' apple cultivar grafted on two clonal rootstocks during two consecutive years

\begin{tabular}{|c|c|c|}
\hline \multicolumn{2}{|l|}{ Parameter } & $\begin{array}{c}\text { Fruit weight } \\
(\mathrm{g})\end{array}$ \\
\hline \multicolumn{3}{|c|}{ Rootstock (A) } \\
\hline \multicolumn{2}{|l|}{ M.9 T337 } & $176.25 \pm 0.75 \mathrm{a}$ \\
\hline \multicolumn{2}{|l|}{ M.26 } & $168.12 \pm 0.64 b$ \\
\hline \multicolumn{3}{|l|}{ Year (B) } \\
\hline \multicolumn{2}{|l|}{2018} & $171.37 \pm 1.02 \mathrm{a}$ \\
\hline \multicolumn{2}{|l|}{2019} & $173.00 \pm 2.04 \mathrm{a}$ \\
\hline \multicolumn{3}{|c|}{ Interaction $\mathrm{A} \times \mathrm{B}$} \\
\hline \multirow[t]{2}{*}{ M.9 T337 } & 2018 & $174.75 \pm 0.75 a$ \\
\hline & 2019 & $177.75 \pm 0.74 \mathrm{a}$ \\
\hline \multirow[t]{2}{*}{ M.26 } & 2018 & $168.00 \pm 0.50 \mathrm{a}$ \\
\hline & 2019 & $168.25 \pm 1.75 \mathrm{a}$ \\
\hline \multicolumn{3}{|l|}{ ANOVA } \\
\hline \multicolumn{2}{|l|}{ A } & $*$ \\
\hline \multicolumn{2}{|l|}{ B } & ns \\
\hline \multicolumn{2}{|l|}{$A \times B$} & ns \\
\hline
\end{tabular}

The different letter(s) in the column indicate significant differences among means for each rootstock and fruit tissue at $P \leq 0.05$ by LSD test.

The asterisk in the column indicates significant differences at $P \leq 0.05$ by $F$ test. ns: not significant.

Data in Table 2 revealed that the content of chemicals significantly varied between rootstocks and also between fruit tissues. In addition, the effect of the rootstock $\times$ tissue interaction on all evaluated biochemical compounds was significant. Sasnauskas et al. (2007) also reported that the fruit quality and 
biochemical composition of apple were significantly influenced by scion (cultivar), rootstock and their interaction.

Titratable acidity can be an important indicator of taste of apple fruits (Harker et al., 2002) and their internal quality, since consumers often have distinct preferences for acid or sweet tasting apples (Daillant-Spinnler et al., 1996). The predominant acid in apples is malic acid, followed by citric acid etc. (Nour et al., 2010).

Table 2. Phenolic compounds and total antioxidant capacity of apple $c v$. 'Hapke' grafted on two clonal rootstocks

\begin{tabular}{|c|c|c|c|c|c|c|}
\hline Parameter & & $\begin{array}{l}\text { Titratable } \\
\text { acidity } \\
(\%)\end{array}$ & $\begin{array}{c}\text { Vitamin C } \\
(\mathrm{mg} \mathrm{100/g} \mathrm{fw)}\end{array}$ & $\begin{array}{c}\text { Total phenolic } \\
\text { content } \\
\text { (mg GAE 100/g fw) }\end{array}$ & $\begin{array}{l}\text { Total flavonoid } \\
\text { content } \\
\text { (mg CE 100/g fw) }\end{array}$ & $\begin{array}{c}\text { Total } \\
\text { antioxidant } \\
\text { capacity } \\
(\mu \mathrm{g} \text { AA/g fw })\end{array}$ \\
\hline \multicolumn{7}{|c|}{ Rootstock (A) } \\
\hline M.9 Т337 & & $0.26 \pm 0.00 \mathrm{~b}$ & $8.25 \pm 0.02 b$ & $208.00 \pm 0.02 b$ & $93.74 \pm 0.01 b$ & $103.37 \pm 0.00 \mathrm{~b}$ \\
\hline M.26 & & $0.35 \pm 0.01 \mathrm{a}$ & $11.35 \pm 0.00 \mathrm{a}$ & $210.35 \pm 0.01 \mathrm{a}$ & $99.89 \pm 0.02 \mathrm{a}$ & $107.87 \pm 0.01 \mathrm{a}$ \\
\hline \multicolumn{7}{|l|}{ Tissue (B) } \\
\hline Flesh & & $0.13 \pm 0.00 \mathrm{~b}$ & $8.65 \pm 0.01 b$ & $201.49 \pm 0.02 b$ & $71.18 \pm 0.02 b$ & $103.37 \pm 0.01 b$ \\
\hline Peel & & $0.48 \pm 0.00 \mathrm{a}$ & $10.95 \pm 0.00 \mathrm{a}$ & $216.87 \pm 0.01 \mathrm{a}$ & $122.44 \pm 0.01 \mathrm{a}$ & $108.82 \pm 0.01 \mathrm{a}$ \\
\hline \multicolumn{7}{|c|}{ Interaction $\mathrm{A} \times \mathrm{B}$} \\
\hline \multirow{2}{*}{ M.9 Т337 } & Flesh & $0.10 \pm 0.00 \mathrm{~d}$ & $7.05 \pm 0.02 \mathrm{~d}$ & $200.55 \pm 0.03 \mathrm{~d}$ & $67.07 \pm 0.01 \mathrm{~d}$ & $101.28 \pm 0.01 \mathrm{~d}$ \\
\hline & Peel & $0.41 \pm 0.01 \mathrm{~b}$ & $9.46 \pm 0.01 \mathrm{c}$ & $215.46 \pm 0.01 \mathrm{~b}$ & $120.41 \pm 0.00 \mathrm{~b}$ & $105.46 \pm 0.01 \mathrm{c}$ \\
\hline \multirow{2}{*}{ M.26 } & Flesh & $0.17 \pm 0.00 \mathrm{c}$ & $10.25 \pm 0.00 b$ & $202.42 \pm 0.01 \mathrm{c}$ & $75.30 \pm 0.02 c$ & $107.40 \pm 0.00 \mathrm{~b}$ \\
\hline & Peel & $0.54 \pm 0.01 \mathrm{a}$ & $12.45 \pm 0.00 \mathrm{a}$ & $218.29 \pm 0.01 \mathrm{a}$ & $124.48 \pm 0.02 \mathrm{a}$ & $110.24 \pm 0.01 \mathrm{a}$ \\
\hline \multicolumn{7}{|l|}{ ANOVA } \\
\hline A & & $*$ & $*$ & $*$ & * & $*$ \\
\hline B & & * & $*$ & * & * & * \\
\hline $\mathrm{A} \times \mathrm{B}$ & & $*$ & $*$ & $*$ & * & $*$ \\
\hline
\end{tabular}

The different letter(s) in columns indicate significant differences among means for each rootstock and fruit tissue at $P \leq 0.05$ by LSD test.

The asterisks in columns indicate significant differences at $P \leq 0.05$ by $F$ test. ns: not significant.

In the present study, M.26 induced a higher TA content than M.9 T337 in 'Hapke' fruits. However, in our earlier work on apple (Milošević et al., 2018), M.9 T337 caused a higher total acid content in 'Red Chief ${ }^{\circledR}$ Camspur' fruits than the semi-dwarf M.4 and MM.106 rootstocks, respectively. In many pomologies worldwide, M.9 T337 and M.26 rootstocks are classified as dwarf rootstocks for apple, with M.26 as somewhat more vigorous. Also, as the canopy of $c v$. 'Hapke' 
grafted on M.26 was sparse, the fruits were more exposed to sunlight, which contributed to the increased acid content of the fruit (Avad et al., 2000).

Hence, studies on the effect of rootstock on the accumulation of TA in apple fruits revealed benefits of dwarfing rootstocks, as previously reported by Mainla et al. (2011). In our study, 3.7-fold more TA were found in the peel than in the apple flesh, which is in agreement with the results of other authors (Drogoudi et al., 2008; Milošević et al., 2018). Drogoudi et al. (2008) also reported that the green peel of 'Granny Smith' apple had the highest TA content, as opposed to the lowest in the yellowish-green peel of 'Fyriki' apple in comparison with seven apple cultivars, indicating an important role of peel colour in TA accumulation (Nour et al., 2010). Also, results from more studies reported that clones (genotypes) of the 'Red Delicious' group had smaller to moderate TA contents (Koukourikou-Petridou et al., 2007; Ahmed et al., 2013; Milošević et al., 2018). In general, our range of TA values was within the range determined by other researchers (Sasnauskas et al., 2007; Nour et al., 2010; Contessa and Botta, 2016).

In our study, higher contents of vitamin C, TPC, TFC and TAC were found in $c v$. 'Hapke' grafted on M.26 than on M.9 T337, and the peel was a better source of these compounds in comparison with the fruit flesh (Table 2). This is in accordance with the previous results obtained for several apple genotypes showing that the peel tissue is the fruit portion with the highest bioactivity (Leccese et al., 2009).

Studies on the influence of apple rootstock (Mainla et al., 2011; Kviklys et al., 2014) on the accumulation and distribution of phenolic compounds in apple fruit tissues (Wolfe et al., 2003; Chinnici et al., 2004; Drogoudi et al., 2008; Leccese et al., 2009) revealed benefits of dwarfing rootstocks (Milošević et al., 2018). Awad et al. (2000) indicated an increase of some phenolic compounds such as quercetin in apple peel due to better sun-exposure.

As regards the effect of rootstock on the contents of these compounds in this trial, we did not identify higher levels of tested compounds in fruits from trees on the dwarfing M.9 T337 rootstock. Probably, the slender canopy with better light conditions of M.26 may be the major reason for this phenomenon in our study. Similar results were found by Kviklys et al. (2014).

Vitamin C (also called ascorbic acid, ascorbate, AA) is a water soluble organic compound that participates in many biological processes i.e. in maintaining human health and is positively correlated with antioxidant activity. In the present study, the apple peel contained a 1.27 times higher vitamin $\mathrm{C}$ content and 1.05 times higher antioxidant activity compared with the flesh. This is in accordance with the previous results obtained in several apple genotypes showing that the peel tissue is the fruit portion with the highest bioactivity (Drogoudi et al., 2008; Leccese et al., 2009). Drogoudi et al. (2008) reported much lower values of vitamin $\mathrm{C}$ in the flesh of several apples than those obtained in our study, whereas Planchon et al. (2004) and Nour et al. (2010) reported 


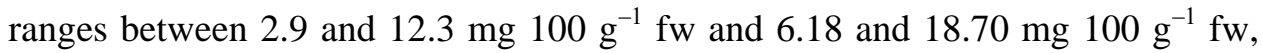
which supported our results. Ahmed et al. (2013) reported the values of vitamin $\mathrm{C}$ in fruits of 'Red Delicious' on MM.111 between $6.98 \%$ ('Red Chief') and $7.83 \%$ ('Starking Delicious'). In addition, ancient or old apples are richer in vitamin $\mathrm{C}$ and phenolic compounds than newly bred and/or commercial apples, but generally depending on the genetics of cultivar, fruit position in the trees, fruit size, fruit skin colour and maturity stage (Contessa and Botta, 2016). Interestingly, the flesh of 'Hapke' on M.26 had better TAC values than the peel of fruits of this cultivar on M.9 T337.

The comparison of the TPC and TFC values obtained in the present study with those of other studies suggests similar trends although differences in the units used and analytical methods employed make a direct comparison difficult (Drogoudi et al., 2008). For example, the edible part of peeled apple fruits contained TPC between 31.42 and $90.12 \mathrm{mg} \mathrm{GAE} 100 \mathrm{~g}^{-1}$ fw (Contessa and Botta, 2016), whereas Kähkönen et al. (1999) reported $12 \mathrm{mg} \mathrm{GAE} 100 \mathrm{~g}^{-1} \mathrm{dw}$ in the flesh of an unspecified cultivar. However, higher contents of phenolic compounds in the peel than the flesh were also reported by other researchers (Wolfe et al., 2003; Chinnici et al., 2004; Leccese et al., 2009; Milošević et al., 2018). For instance, Leccese et al. (2009) reported that the content of TPC was higher in the peel (varied between 1.72 and $3.75 \mathrm{mg} \mathrm{GAE} \mathrm{g}^{-1} \mathrm{fw}$ ) than in the

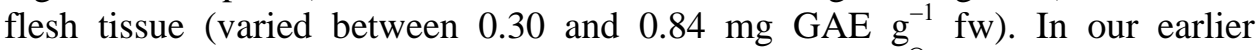
research (Milošević et al., 2018), the peel of 'Red Chief ${ }^{\circledR}$ Camspur' contained TPC between 203.12 and $340.05 \mathrm{mg}$ GAE $100 \mathrm{~g}^{-1} \mathrm{dw}$, and TFC between 48.34 and $77.42 \mathrm{mg}$ RUE $100 \mathrm{~g}^{-1} \mathrm{dw}$. In this study, the peel was also a richer source of these compounds than the edible part of the fruits.

The significant interaction between rootstock and fruit tissue indicated that the accumulation and distribution of acids and phenolic compounds and antioxidant activity in apple fruits have a complex nature and can be attributed to the biochemical and physiological processes during their growth, development and maturity.

\section{Conclusion}

The obtained results showed that rootstocks significantly modified the fruit weight of 'Hapke' apples, being 1.04 times higher on M.9 T337 rootstock than on M.26. Year alone and the rootstock $\times$ year interaction had no effect on this property, indicating a stronger effect of rootstock than the other sources of variation. On the other hand, rootstock, fruit tissue and their interaction significantly changed titratable acidity and the contents of vitamin $\mathrm{C}$ and phenolic compounds in the fruits of this cultivar. Higher values were found on M.26 rootstock than on M.9 T337. The peel was a richer source of acidity and phenolic compounds, and had better antioxidant activity than the fruit flesh. 
The physicochemical characteristics of 'Hapke' apples should be considered together for the choice of better rootstocks under growing conditions aimed at selecting rootstocks with improved fruit weight, acidity, phenolic compounds and antioxidant capacity.

\section{References}

Ahmed M.J, Gillani G.M.S., Kiani F.A. (2013): Response of apple (Malus domestica Borkh.) cultivars grafted on two rootstocks under sub-humid temperate climate of Azad Jammu and Kashmir. Pakistan Journal of Agricultural Sciences, 50 (3): 379386.

Arya S.P., Mahajan M., Jain P. (2000): Non-spectrophotometric methods for the determination of vitamin C. Analytica Chimica Acta, 417 (1): 1-14.

Asif Ali M., Raza H., Azam Khan M., Manzoor H. (2004): Effect of different periods of ambient storage on chemical composition of apple fruit. International Journal of Agriculture and Biology, 6 (2): 568-571.

Awad M.A., de Jager A., van Westing L.M. (2000): Flavonoid and chlorogenic acid levels in apple fruit: Characterisation of variation. Scientia Horticulturae, 83 (3-4): 249-263.

Chinnici F., Bendini A., Gaiani A., Riponi C. (2004): Radical scavenging activities of peels and pulps from cv. Golden delicious apples as related to their phenolic composition. Journal of Agricultural and Food Chemistry, 52 (15): 4684-4689.

Contessa C., Botta R. (2016): Comparison of physicochemical traits of red-fleshed, commercial and ancient apple cultivars. Horticultural Science (Prague), 43 (4): 159166.

Daillant-Spinnler B., MacFie H.J.H, Beyts P.K., Hedderley D. (1996): Relationships between perceived sensory properties and major preference directions of 12 varieties of apples from the southern hemisphere. Food Quality and Preference, 7 (2): 113126.

Drogoudi P.D., Michailidis Z., Pantelidis G. (2008): Peel and flesh antioxidant content and harvest quality characteristics of seven apple cultivars. Scientia Horticulturae, 115 (2): 149-153.

FAOSTAT (2019): http://www.fao.org/faostat/en/\#data/QC

Greenhalgh W.J., Godley G.L., Menzies R. (1977): Studies of fruit shape in apples: response to gibberellin and cytokinin sprays. Australian Journal of Experimental Agriculture and Animal Husbandry, 17 (86): 505-509.

Harker F.R., Marsh K.B., Young H., Murray S.H., Gunson F.A., Walker S.B. (2002): Sensory interpretation of instrumental measurements 2: sweet and acid taste of apple fruit. Postharvest Biology and Technology, 24 (3): 241-250.

Kähkönen M.P., Hopia A.I., Vuorela H.J., Rauha J.P., Pihlaja K., Kujala T.S., Heinonen M. (1999): Antioxidant activity of plant extracts containing phenolic compounds. Journal of Agricultural and Food Chemistry, 47 (10): 3954-3962.

Koukourikou-Petridou M.A., Voyiatzis D.G., Stylianidis D.K., Sotiropoulos T.E., Therios I.N. (2007): Effects of some growth regulators on pre- and after-storage quality of 'Red Chief Delicious' apples. European Journal of Horticultural Science, $72(1): 8-11$. 
Kviklys D., Liaudanskas M., Janulis V., Viškelis P., Rubinskienė M., Lanauskas J., Uselis N. (2014): Rootstock genotype determines phenol content in apple fruits. Plant, Soil and Environment, 60 (5): 234-240.

Leccese A., Bartolini S., Viti R. (2009): Antioxidant properties of peel and flesh in 'GoldRush' and 'Fiorina' scab-resistant apple (Malus domestica) cultivars. New Zealand Journal of Crop and Horticultural Science, 37 (1): 71-78.

Mainla L., Moor U., Karp K., Püssa T. (2011): The effect of genotype and rootstock on polyphenol composition of selected apple cultivars in Estonia. ŽemdirbystèAgriculture, 98 (1): 63-70.

Marini R.P. (2001): Estimating Mean Fruit Weight and Mean Fruit Value for Apple Trees: Comparison of Two Sampling Methods with the True Mean. Journal of the American Society for Horticultural Science, 126 (4): 503-510.

Markuszewski B., Kopytowski J. (2008): Transformations of chemical compounds during apple storage. Sodininkyste ir Daržininkystè, 27 (2): 329-338.

Milošević N., Milošević T., Lukić M. (2014): Impact of Progerbalin LG® on the apple fruit physical attributes. Plant Growth Regulation, 72 (2): 105-112.

Milošević T., Milošević N., Mladenović J. (2018): Role of apple clonal rootstocks on yield, fruit size, nutritional value and antioxidant activity of 'Red Chief ${ }^{\circledR}$ Camspur' cultivar. Scientia Horticulturae, 236 (10): 214-221.

Milošević T., Milošević N., Mladenović J. (2019): Tree vigor, yield, fruit quality, and antioxidant capacity of apple (Malus domestica Borkh.) influenced by different fertilization regimes: preliminary results. Turkish Journal of Agriculture and Forestry, 43 (1): 48-57.

Nour V., Trandafir I., Ionica M.E. (2010): Compositional Characteristics of Fruits of several Apple (Malus domestica Borkh.) Cultivars. Notulae Botanicae Horti Agrobotanici Cluj-Napoca, 38 (3): 228-233.

Paunović G., Bošković-Rakočević Lj., Ilić R. (2015): Effect of high Al content in the soil on vegetative rootstocks for apple. Acta Agriculturae Serbica, 20 (40): 165-171.

Planchon V., Lateur M., Dupont P., Lognay G. (2004): Ascorbic acid level of Belgian apple genetic resources. Scientia Horticulturae, 100 (1-4): 51-61.

Prieto P., Pineda M., Aguilar M. (1999): Spectrophotometric quantification of antioxidant capacity through the formation of a phosphomolybdenum complex: Specific application of vitamin E. Analytical Biochemistry, 269 (2): 337-341.

Sasnauskas A., Gelvonauskiene D., Viskelis P. (2007): Yield and fruit quality of fifteen apple cultivars. Sodininkystė ir Daržininkystè, 26 (3): 149-158.

Singleton V.L., Orthofer R., Lamucla-Raventos R.M. (1999): Analysis of total phenols and other oxidative substrates and antioxidant by means of Folin-Ciocalteau reagent. Methods Enzymology, 299: 152-176.

Tabakov S.G., Yordanov A.I., Kaymakanov P.V. (2016): Comparative study of apple rootstocks 'M9-T337' and 'Supporter 4 Pi 80' with seven cultivars. Acta Horticulturae, 1139: 203-208.

Zhishen J., Mengcheng T., Jianming W. (1999): The determination of flavonoid contents in mulberry and their scavenging effects on superoxide radicals. Food Chemistry, 64 (4): 555-559.

Wolfe K., Wu X., Liu R.H. (2003): Antioxidant activity of apples peels. Journal of Agricultural and Food Chemistry, 51 (3): 609-614. 


\title{
ULOGA PODLOGE I TKIVA PLODA JABUKE U ANTIOKSIDATIVNOJ AKTIVNOSTI
}

\author{
Tomo Miloševicí ${ }^{1}$, Nebojša Milošević ${ }^{2}$, Jelena Mladenović ${ }^{3}$ \\ ${ }^{1}$ Katedra za voćarstvo i vinogradarstvo, Agronomski fakultet, Univerzitet u \\ Kragujevcu, 32000 Čačak, Republika Srbija \\ ${ }^{2}$ Odeljenje za pomologiju i oplemenjivanje voćaka, Institut za voćarstvo, Čačak, \\ 32000 Čačak, Republika Srbija \\ ${ }^{3}$ Katedra za hemiju i hemijsko inženjerstvo, Agronomski fakultet, Univerzitet u \\ Kragujevcu, 32000 Čačak, Republika Srbija

\section{Rezime}

Tokom dve uzastopne godine (2018 i 2019) ispitivali smo uticaj dve vegetativne podloge na masu ploda, sadržaj nekih nenutritivnih jedinjenja i ukupni antioksidativni kapacitet u mezokarpu i pokožici ploda jabuke sorte 'Hapke'. Rezultati su pokazali da je masa ploda bila veća na podlozi M.9 T337 u odnosu na M.26, ali slična u obe godine istraživanja. Podloga M.26 je značajno poboljšala sadržaj ukupnih kiselina, vitamina $\mathrm{C}$, ukupnih fenola i ukupnih flavonoida i ukupni antioksidativni kapacitet u poređenju sa M.9 T337.

Što se tiče tkiva ploda, pokožica je bila značajno bolji izvor ukupnih kiselina, vitamina $\mathrm{C}$ i fenolnih jedinjenja $\mathrm{i}$ imala je veći antioksidativni kapacitet od mezokarpa. Međutim, interakcija podloga $\times$ tkivo za pomenuta jedinjenja pokazuje složenu prirodu njihove akumulacije i distribucije u plodu.

Ključne reči: tkivo ploda jabuke, fenolna jedinjenja, ukupni antioksidativni kapacitet, vitamin C. 